\title{
Cassava biopolymer polyamide hydrogel accelerates healing of induced skin woundsin rats
}

\author{
[Hidrogel de biopolímero de poliamido de mandioca acelera o processo \\ de cicatrização em feridas cutâneas induzidas em ratos] \\ J.D. Vicente ${ }^{1}$, G.R. Santo ${ }^{2}$, G.C. Palin ${ }^{2}$, L.A. Reati ${ }^{2}$, T.K. Urano ${ }^{2}$, \\ W.A. Trindade ${ }^{1}$, P.F.G.P. Amaral ${ }^{1}$, E. Gerônimo ${ }^{1}$, L.K. Otutumi ${ }^{4}$, \\ E.L.B. Lourenço ${ }^{4}$, D.C. Dragunski ${ }^{3}$, R.M. Germano ${ }^{4}$ \\ ${ }^{1}$ Aluno de pós-graduação - Universidade Paranaense - Umuarama, PR \\ ${ }^{2}$ Aluno de graduação - Universidade Paranaense - Umuarama, PR \\ ${ }^{3}$ Universidade Estadual do Oeste do Paraná - Toledo, PR \\ ${ }^{4}$ Universidade Paranaense - Umuarama, PR
}

\begin{abstract}
This study aimed to macroscopically and microscopically evaluate the healing of skin wounds induced in rats by topical application of cassava polyamide biopolymer hydrogel. In total, 32 rats were used and divided into four groups $(n=8)$ : negative control - saline solution; positive control - use of commercial ointment; experimental group - I - ointment + cassava hydrogel; experimental group - II - cassava hydrogel. A $1 \mathrm{~cm}^{2}$ wound induced on the animals dorsum was treated and evaluated. At day 21 postoperation, the animals were sacrificed by anesthetic overdose, and then $1 \mathrm{~cm}^{2}$ of cicatricial skin from the wound region was collected. The material was cut to evaluate healing. In the macroscopic evaluation, complete healing was observed at the end of 21 days. Re-epithelialization was observed histologically; the connective tissue in the negative control, positive, and experimental - I groups was characterized by an abundance of collagen fibers, fibroblasts, and blood vessels. In experimental group - II additional healing was observed, as evidenced by the arrangement of collagen fibers and fibroblasts, and the reduction of neoformed vessels. Thus, we concluded that the hydrogel can assist in healing skin wounds, especially in the remodeling phase.
\end{abstract}

Keywords: cassava starch, fibroplasias, Manihot esculenta, skin

\section{RESUMO}

O objetivo deste estudo foi avaliar macro e microscopicamente a cicatrização de feridas cutâneas induzidas em ratos, a partir da aplicação tópica do hidrogel de biopolímero de poliamido de mandioca. Trinta e dois ratos foram divididos em quatro grupos $(n=8)$ : controle negativo, tratado com solução salina; controle positivo, com pomada comercial; grupo experimental - I, com pomada + hidrogel de mandioca; grupo experimental - II, com hidrogel de mandioca. Feridas induzidas de $1 \mathrm{~cm}^{2}$ no dorso dos animais foram tratadas e avaliadas em intervalos de três a quatro dias. No $21^{\circ}$ dia do pós-operatório, os animais foram mortos por aprofundamento anestésico, em seguida foi coletado $1 \mathrm{~cm}^{2}$ de pele da região cicatricial. O material foi cortado, corado pelas técnicas de hematoxilina-eosina e azocarmine-G, para avaliação da cicatrização. Na avaliação macroscópica, foi observada cicatrização completa no final do período de 21 dias. Histologicamente, observou-se reepitelização, o tecido conjuntivo no grupos controle negativo, positivo e experimental - I se caracterizou pela abundância de fibras colágenas, fibroblastos e vasos sanguíneos. No grupo experimental - II, a cicatrização sugere avanço de etapas, evidenciado pelo arranjo das fibras colágenas, pela redução de fibroblastos e dos vasos neoformados. Assim, foi possível 
concluir que o hidrogel de biopolímero de amido de mandioca pode auxiliar na cicatrização de feridas cutâneas, principalmente na fase de remodelação.

\section{Palavras-chave: amido de mandioca, fibroplasias, Manihot esculenta, pele}

\section{INTRODUCTION}

The cassava (Manihot esculenta Crantz) is a plant belonging to the Euphorbiaceae family, with perennial shrub production. The roots are comprised of $62 \%$ moisture, $1.3 \%$ fiber, $34 \%$ carbohydrates, and $1.1 \%$ ashes. Cassava production is abundant in Brazil (Fraife-Filho and Bahia, 2009).

Biopolymers are polymers formed in nature, of natural origin, during the growth cycle of all organisms. Starch is a highly produced polymer found in potatoes, corn, and rice, with high amylose content and amylopectin, and is easily used in the production of biofilms (Chandra and Rustgi 1998), starch from cassava is also easily converted into edible films (Rossi-Jesus et al., 2015).

In addition to biofilms, hydrogels when hydrated can help decrease the irritation of adjacent tissues after its application. Owing to a low interfacial and superficial fixation of hydrogels and body fluids, hydrogels can be used as a vehicle for other drugs (Bhattarai et al., 2010).

Application of these polymers in the field of biomedicine is becoming increasingly relevant, mainly by remarkable biocompatibility results. From the perspective of sustainability, these products comply with the three pillars of development, namely: economic development, social development, and environmental protection (Farias et al., 2016).

Biodegradation of starch matrices is capable of facilitating active transportation inside the organism, favoring the commercial scale production of the biofilm by pharmaceutical industries, for incorporating medicines into the same (Farias et al., 2016).

The skin is composed of the epidermis with keratinocytes as the main cells, and the dermis with fibroblasts (Isaac et al., 2010). After skin lesion formation, the biological process of healing starts and is divided into three stages: the initial phase of hemostasis, the inflammatory phase with formation of granulation tissue and deposition of extracellular matrix, collagen, elastin and reticular fibers and then, the proliferative phase, which corresponds to the remodeling phase of collagen and cellular matrix (Branco-Neto et al., 2006; Oliveira and Dias, 2012).

Bioactive products have been used as an adjuvant treatment for healing and integrity of normal skin and are being tested as alternative means in the pursuit of natural products for wound treatments (Nakamura et al., 2005). According to Lucena et al. (2015), in an experimental model of skin wounds induced in rats, where a membrane of biopolymers made from sugar cane was used, the characteristics of a complete healing process were observed, similar to conventional methods.

This study aimed to assess the macro and microscopic aspects of the healing process of surgically induced skin wounds in male Wistar rats, at the end of 21 days of treatment, with or without cassava starch biopolymer hydrogel.

\section{MATERIAL AND METHODS}

A total of 32 male Wistar rats (Rattus norvegicus) from the Laboratory of the Universidade Federal do Paraná were used, with ages ranging from 80 to 90 days. The experiment was carried out at the Laboratory of Experimental Research of Pharmacology of the Universidade Paranaense, in an environment with a controlled temperature of $22 \pm 2^{\circ} \mathrm{C}, 12$ hours light-dark cycle, and an exhaust system. All procedures were approved by the Ethics Committee on Animal Use of the Universidade Paranaense (Protocol number 1003/2016).

The cassava polyamide hydrogel was developed in the Chemistry Laboratory of the Universidade do Oeste do Paraná, in collaboration with Universidade Paranaense. The material, after preparation, was dried in a vacuum oven at a temperature of $45^{\circ} \mathrm{C}$ (Rossi-Jesus et al., 2015) and maintained in this condition until further use, 
when it was again pre-gelatinized with the injection of water heated to $50^{\circ} \mathrm{C}$.

Before beginning the experiment, the animals underwent an adaptation period of seven days in the experimental conditions, receiving water and food ad libitum. In this period, the animals were weighed at the mean $\pm 10 \%$ of weight/body, were placed in individual boxes, randomized, and distributed in four groups with $\mathrm{n}=8$ in all groups: Negative control group (GC-N), Positive control group (GC-P), Experimental Group I (GE-I), and Experimental Group II (GE-II).

Prior to the surgery, the rats were fasted for a period of 12 hours, receiving only water. They were subjected to dissociative anesthesia, with ketamine hydrochloride $(100 \mathrm{mg} / \mathrm{kg})$, and xylazine $\quad(13 \mathrm{mg} / \mathrm{kg}), \quad$ administered intraperitoneally (adapted from Barboza et al., 2014). They were considered to be anesthetized upon immobility and an absence of response to stimulation at the base of the tail with hemostatic tweezers, with maintenance of respiratory frequency and amplitude.

Positioned in ventral decubitus and after securing the posterior and inferior limbs, trichotomy was performed using a shear. After trichotomy, demarcation of the area was performed for inducing the surgical wound with the aid of a demographic pen and a metallic mold of $1.0 \mathrm{~cm}^{2}$, which was previously prepared, thus allowing the standardization of incisions in all rats. The interscapular region was chosen for the surgical procedure owing to the ease of handling for dressing changes, and considering the impossibility of the rats licking the wound.

In sequence, antisepsis was performed with polyvinylpyrrolidone-iodine at $10 \%$ by scrubbing, topical application of alcohol and iodine, and placement of the sterile fenestrated surgical field. The rats were subjected to surgical excision, with the help of a scalpel blade $n^{\circ} 15$, Metzenbaum scissors, and anatomic tweezers, removing the epidermis, dermis, and part of the subcutaneous screen on the hypodermis. Hemostasis was performed by digital compression using sterile gauze, and when necessary, moistened with saline solution at a temperature of about $8^{\circ} \mathrm{C}$.
After removal of the skin fragment, each group received the first dressing with application of products using sterile spatulas: GC-N, the induced wound was washed with saline solution, and then received nonionic vehicle, devoid of any substance and was covered with sterile gauze, bandaged with a surgical mesh and micropore tape and secured at the ends with a surgical tape; GC-P, the wound was washed with saline solution, and then treated with ointment based on gentamicin, sulfanilamide, sulphadiazine, urea and vitamin A palmitate, followed by bandaging; GE-I, after being washed with saline solution, the cassava polyamide hydrogel and ointment were applied followed by bandaging; GE-II, the area was washed with saline solution, covered with the cassava polyamide hydrogel, followed by bandages.

The animals spent the postoperative period in individual boxes. In the pre-surgical conditions and after wearing of anesthesia, the pain was evaluated according to the criteria of the Rat Grimace Scale (RGS) (Sotocinal et al., 2011), the pain was detected, and its level was evaluated. Each rat received morphine sulfate $(5 \mathrm{mg} / \mathrm{kg}$ body weight) by intramuscular administration (Ong and Rodrigues, 2013). The same evaluation was carried out for five days post-surgery, in order to keep the animals comfortable.

The bandages and dressing changes, followed by macroscopic evaluation of surgical wounds, were performed at intervals of 72 hours, from the surgery until euthanasia. At each change, evaluation of surgical wounds was performed, according to the following criteria: 1 - presence of necrotic tissue; 2 - presence of granulation tissue; 3 - signs of infection; 4 - Characteristics of the exudate such as: (a) serous, serous-bloody, bloody, b) volume, c) odor; 5 - pain by GRS scale; 6 - tissue alterations such as erythema, edema, cyanosis, crust; and 7 - characteristics of the lesion and its extension.

The wound size was measured with the aid of a digital pachymeter, the surgical wound was measured in the craniocaudal and lateral-lateral directions, at the region with the greatest extension. Euthanasia was performed on day 21 post-operation (P.Op.), the rats were subjected to an overdose of anesthesia in a chamber with isoflurane and sacrificed. Samples were then 
collected from the skin of the cicatricial region of all rats with a border of intact skin of approximately $1 \mathrm{~cm}^{2}$. The material was then fixed in a neutral solution of $10 \%$ buffered formalin.

After fixation, the samples followed the histological routine stages of dehydration, diaphanization, and paraffin embedding. The paraffin blocks containing the material were then cut into $6-\mu \mathrm{m}$-thick sections, in a direction perpendicular to the skin surface, with the central scar bordered by an area of intact skin. The slides were stained with hematoxylin-eosin (HE) for morphological evaluation of tissues and with Azocarmime $G$ to evaluate the collagen fibers, and then mounted with synthetic resin and a slide overlapping the cuts.

With the aid of a Nikon ${ }^{\circledR}$ trinocular microscope (Eclipse E-200 - Nikon - Brazil) with an attached digital camera, Model Moticam $5^{\circledR} \quad(5$ Megapixels - Motic - Brazil) images were obtained from microscopic fields to assess the number of blood vessels, and the presence and arrangement of collagen fibers in the neoformed tissue. Qualitative observations were made in the process of re-epithelialization and the presence of a crust.

The quantitative variables were presented by their means and evaluated by analysis of variance (ANOVA), followed by the comparison among the means of different groups by Tukey's post hoc test.

\section{RESULTS AND DISCUSSION}

The surgery was performed without complications. All rats recovered from the anesthesia and there were no deaths during the entire experiment. The cassava polyamide hydrogel applied in this study showed no signs of toxicity in different organs of Wistar rats, when administered at different doses (Rossi-Jesus et al., 2015).

Changes in the normal behavior such as arched posture, vocalization to be handled, piloerection, and weight loss are classified as pain, and the skin wounds and small incisions are classified as mild pain (Ong and Rodrigues, 2013). Therefore, the weight loss observed (Table 1) and evaluation through the RGS, allowed to determine that the degree of pain presented by all animals regardless of the group was light. However, the rats received morphine at a dose of $5 \mathrm{mg} / \mathrm{kg}$ of body weight by the intramuscular route every 24 hours. Day 6 after surgery, the rats showed no more signs of pain, and the use of analgesic was stopped. This procedure and the clinical assessments performed on the first five days P.Op. showed that the rats made an adequate recovery.

Rats are social animals; however, they present cannibalism in adverse conditions (Van Loo et al., 2005). Therefore, each rat was housed individually to avoid this situation. To compensate for the lack of socialization and promote distraction, environmental enrichment was adopted using non-toxic polypropylene balls, as rats under conditions of environmental stress or physiological effects can also cause self-mutilation. Environmental enrichment is a method used to improve the quality of life and the welfare of captive species (Van Loo et al., 2005).

Table 1. Evaluation of the average weight of rats $(\mathrm{g})$ on days 3,10 , and 17 post-operation

\begin{tabular}{|c|c|c|c|c|c|}
\hline \multirow{2}{*}{ Period } & \multicolumn{4}{|c|}{ Weight Assessment (g) } & \multirow{2}{*}{$\mathrm{p}$ value } \\
\hline & GC-N & GC-P & GE-I & GE-II & \\
\hline day 3 & 284 & 283 & 287 & 285 & p0.757969 \\
\hline day 10 & 264 & 259 & 268 & 264 & p0.243078 \\
\hline day 17 & 288 & 291 & 291 & 292 & p0.860689 \\
\hline
\end{tabular}

GC-N negative control group; GC-P Positive control group; GE-I experimental group I; GE-II experimental group II. There were no significant differences by ANOVA. 
Its application has been increasing due to scientific and ethical reasons. However, currently, no manual of good laboratory practice or regulation of well-being describes enrichment as a standard (Santos and Fontes, 2013). In the study in question, such a procedure was considered important in order to prevent alteration of the obtained results. Stress and pain may hinder healing (Sampaio, 2010).

Blood secretion in the wounds was observed until day 6 P.Op., with the exception of GC-P, which showed no bleeding during the surgical wound dressings. Secretion of blood was also observed in another similar study, being an expected event in wounds of this type; however, the bleeding must only be controlled by compression with gauze (Branco-Neto et al., 2006).

In macroscopic evaluations it was possible to verify the formation of a protective film over the area, which proved to be efficient compared to the mechanical damage of the bandages. However, this delayed the process of angiogenesis, which can be verified by the paleness of the area (Figure 1, A2). Protection with biofilms is used in wound treatment, with some advantages such as impermeability to water and micro-organisms, maintenance of a wet bed, and a smaller number of dressing changes (Souza, 2016).

In GC-N, granulation tissue was observed in $75 \%$ of the rats, when the surgical wounds were evaluated on day 6 P.Op. By days 10 and 13, $87.5 \%$ of rats had granulation tissue. A crust was observed from day 13 in $37.5 \%$ of rats and on day 17, it was present in all rats (Figure1: C1 to $\mathrm{F} 1)$. In GC-P, granulation tissue was observed in $87.5 \%$ of the rats on day 6 , and a crust was formed by day 13 in $12.5 \%$ of the rats, with an increase to $75 \%$ on day 17 (Figure1: C2 to F2). In GE-I, granulation tissue was observed in all rats by day 3 P.Op., extending until day 6 . On day 10 it was present in $75 \%$ of the rats. A crust was observed on day 10 in $50 \%$ of the rats, on day 13 in $62.5 \%$, and on the remaining by day 17 (Figure1: B3 to F3).

Similar to GE-I, the formation and exacerbation of granulation tissue occurred from day 3 P.Op. in GE-II. The crust was present in $87.5 \%$ of rats on day 10 , reducing to $62.5 \%$ on day 13 , and absent on day 17 (Figure1: B4 to F4). These findings analyze the occurrence of granulation tissue, which was observed on day 3 after tissue injury Berry et al., 2003), and might emerge at around day 5 (O'leary et al., 2002). The granular aspect is due to the presence of capillary sprouts and fibroblasts in the region of the surgical wound, which also gives a bright appearance to the site (O'leary, 2002; Berry et al., 2003).

The granulation tissue and the final stage of the healing process was characterized by progressive reduction and absence of the crust, in GE-II, treated with cassava polyamide hydrogel, by the end of the experiment on day 21. Similar results were obtained in a study with a hydrogel derived from policaju and chitosan polysaccharide in rats (Aragão-Neto et al., 2017), as well as an experiment in dogs using a biopolymer membrane of sugar cane, in natura (Coelho et al., 2002). Such positive results in tissue healing suggest an acceleration in the healing process, as well as modulation of the inflammatory process. The wounds were measured using a digital caliper to evaluate the craniocaudal and laterolateral dimensions and the means of the results are shown in Tables 2 and 3.

The reduction of wound margins in the craniocaudal plane was not observed between days 3 and 6 of evaluation, and after day 10 , there was no statistical difference in all the means of areas measured from all the groups assessed (Table 2). However, in the latero-lateral plane, the wound regression can already be evidenced in the means of the measurements from day 6 P.Op., except for GE-II (Table 3). In the comparison among means, the treated groups showed no significant differences among themselves. 


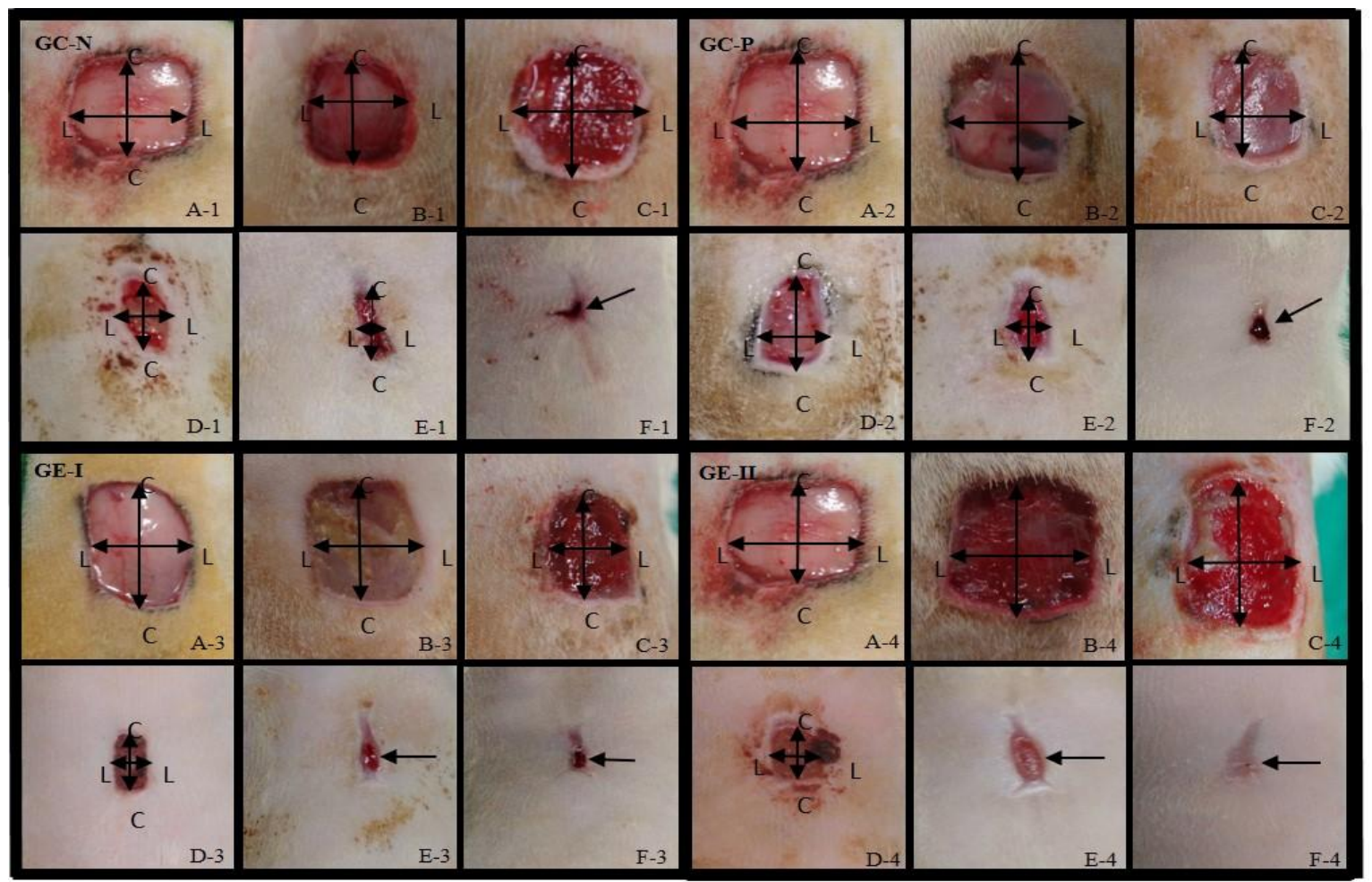

Figure 1. Microscopic aspects of healing of skin wounds induced in male Wistar rats on the day of surgery, and days 3, 6, 10, 13, and 17 postoperatively, of groups: Negative Control group (GC-N) A1 to F1, only washed with saline solution; Positive Control Group (GC-P) A2 to F2, treated with ointment; Experimental Group - I (GE-I) A3 to F3, treated with ointment and cassava polyamide biopolymer hydrogel; Experimental Group - II (GE-II) A4 to F4, with cassava polyamide hydrogel.

Table 2. Evaluation of the means of skin wounds $(\mathrm{mm})$ in male Wistar rats along the healing process of the negative control group (GC-N) treated with saline solution, positive control (GC-P) treated with ointment (anti-infectious, epithelizing and healing) experimental, I (GE-I) treated with ointment (antiinfectious epithelizing and healing) and cassava polyamide hydrogel, and experimental - II (GE- II) treated with cassava polyamide hydrogel in the craniocaudal plane, on days 3, 6, 10, 13, and 17 postoperation

\begin{tabular}{lcccc}
\hline \multirow{2}{*}{ Evaluation } & \multicolumn{4}{c}{ Craniocaudal Measurement (mm) } \\
\cline { 2 - 4 } & GC-N & GC - P & GE - I & GE - II \\
\hline day 3 & $13.58^{\mathrm{a}}$ & $13.63^{\mathrm{a}}$ & $11.79^{\mathrm{a}}$ & $14.60^{\mathrm{a}}$ \\
day 6 & $12.16^{\mathrm{a}}$ & $12.55^{\mathrm{a}}$ & $10.33^{\mathrm{a}}$ & $15.92^{\mathrm{a}}$ \\
day 10 & $7.42^{\mathrm{b}}$ & $9.90^{\mathrm{b}}$ & $8.11^{\mathrm{b}}$ & $9.44^{\mathrm{b}}$ \\
day 13 & $4.81^{\mathrm{c}}$ & $6.00^{\mathrm{c}}$ & $4.47^{\mathrm{c}}$ & $7.20^{\mathrm{c}}$ \\
day 17 & $1.48^{\mathrm{d}}$ & $2.30^{\mathrm{d}}$ & $2.01^{\mathrm{d}}$ & - \\
\hline
\end{tabular}

Different letters in columns indicate statistically significant differences by ANOVA, confirmed by Tukey's test. 
Table 3. Evaluation of the means of skin wounds $(\mathrm{mm})$ in male Wistar rats along the healing process of the negative control group (GC-N) treated with saline solution, positive control (GC-P) treated with ointment (anti-infectious, epithelizing and healing), experimental I (GE-I) treated with ointment (antiinfectious epithelizing and healing) and cassava polyamide hydrogel, and experimental - II (GE- II) treated with cassava polyamide hydrogel in the latero-lateral plane, on days 3, 6, 10, 13, and 17 postoperation

\begin{tabular}{lcccc}
\hline \multirow{2}{*}{ Evaluation } & \multicolumn{4}{c}{ Latero-Lateral Measurement (mm) } \\
\cline { 2 - 4 } & GC-N & GC $-\mathrm{P}$ & GE - I & GE - II \\
\hline day 3 & $12.21^{\mathrm{a}}$ & $11.95^{\mathrm{a}}$ & $12.32^{\mathrm{a}}$ & $13.68^{\mathrm{a}}$ \\
day 6 & $9.70^{\mathrm{b}}$ & $9.70^{\mathrm{b}}$ & $9.45^{\mathrm{b}}$ & $13.28^{\mathrm{a}}$ \\
day 10 & $4.82^{\mathrm{c}}$ & $6.48^{\mathrm{c}}$ & $4.46^{\mathrm{c}}$ & $4.60^{\mathrm{b}}$ \\
day 13 & $2.15^{\mathrm{d}}$ & $2.73^{\mathrm{d}}$ & $2.01^{\mathrm{d}}$ & $2.21^{\mathrm{c}}$ \\
day 17 & $0.80^{\mathrm{d}}$ & $1.03^{\mathrm{e}}$ & $0.89^{\mathrm{d}}$ & - \\
\hline
\end{tabular}

Different letters in columns indicate statistically significant differences by ANOVA, confirmed by Tukey's test.

Rats are considered as animals with loose skin with skin properties peculiar to the species, with an emphasis on the presence of a muscle in the panniculus carnosus being even more pronounced, which allows wound contraction (Marx and Mou, 2002). This results in the healing process following different ways in the different planes studied, as the tensile strength on the back of the animal can lead to more accelerated healing in the latero-lateral plane than in the craniocaudal. The average time to complete the healing of all wounds observed macroscopically was 21 days, except for GE - II, which presented complete healing on day 17 P.Op. (Figure 1, F4).

Similar to the macroscopic observations, evaluation of histological sections of the healing area, collected after the animals were euthanized day 21 after beginning the experiment, all groups showed a complete re-epithelialization process (Figure 2, C1, C2 and C3).

Characteristic of the proliferative phase, reepithelialization occurs by an increase in the size, division, and migration of cells in the basal layer of the epidermis and the edges, when the wound is superficial, and only from the edges when the wound is deep in the repair area of the underlying connective tissue (Mandelbaum et al., 2003; Mendonça and Coutinho-Neto, 2009). Different growth factors are considered responsible for the increase in mitosis and consequent hyperplasia of the epithelium (Mandelbaum et al., 2003)

Using hydrogels of various origins such as policaju-chitosan in wounds of healthy animals (Aragão-Neto et al., 2017) and in diabetic animals (Souza, 2016), the process of reepithelialization was completed at the end of 14 days postoperatively, demonstrating the beneficial effect of these products in the treatment of skin wounds, as demonstrated in this study. As for the organization of collagen fibers, the GC-N, GC-P, and GE-I presented intense fibroplasia, characterized by the abundance of fibroblasts and collagen fibers. However, the arrangement of collagen had an irregular aspect, which is usually present in loose connective tissue. The number of blood vessels in these groups was greater compared to the GE-II, suggestive of a remodeling phase of less advanced stages in the healing process. In these groups, the presence of annexes of the healing skin were not observed in areas such as hair, sebaceous glands, and sweat glands (Figure 2, A1 to A3; B1 to B3; C1 to C3). Souza (2016) proposed that upon treatment with chitosan hydrogel, the microscopic appearance of a remodeling phase occurs, which reinforces the advancement in the healing process to 14 days after surgery. 


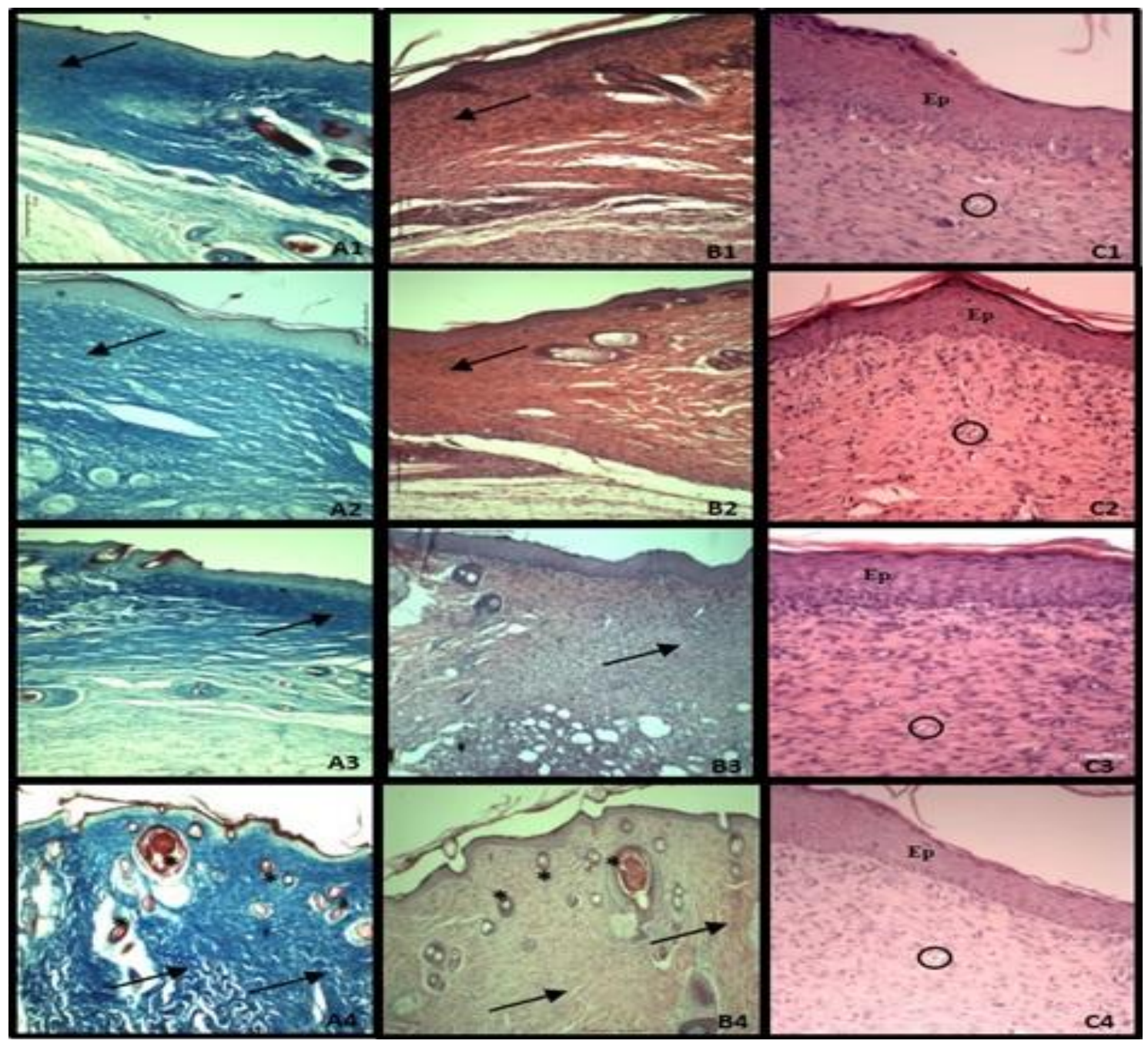

Figure 2. Photomicrographs of healing areas from surgical wounds induced in the dorsal aspect of male Wistar rats of the groups: Negative Control group (GC-N) A1 to C1, only washed with saline solution; Positive Control Group (GC-P) A2 to C2, treated with ointment; Experimental Group - I (GE-I) A3 to C3, treated with ointment and cassava polyamide biopolymer hydrogel; Experimental Group - II (GE-II) A4 to $\mathrm{C} 4$, with cassava polyamide hydrogel. In the images from $\mathrm{C} 1$ to $\mathrm{C} 4$, the complete process of reepithelialization (EP) is evidenced. The arrows in A1, B1, A2, B2, and A3, B3 indicate the presence of collagen; in B1, B2, and B3, a marked presence of fibroblasts is observed. In A4 and B4 (arrows) the arrangement of collagen fibers can be observed, evidencing the remodeling of non-modeled dense connective tissue, with a smaller number of fibroblasts in B4. In C1, C2, C3, and C4 (circle) neoformed blood vessels are observed. In A4 and B4 (asterisk) the emergence of hairs on newly healed tissue is observed. (A1 to A4, staining Azocarmime G 100× magnification; B1 to B4 and C1 to C4, staining H.E., $100 \times$ and $400 \times$ magnification, respectively).

GE-II showed a reduction in the number of fibroblasts and blood vessels. The collagen fibers ended up having a spatial arrangement with more parallel organization among the fibers, evidencing the transition from loose connective tissue to non-modeled dense connective tissue, found in the dermis of the skin of rats; in some cases, regeneration of hair follicles was observed (Figure 2, A4 to C4). This morphological pattern characterizes the final healing stage, in which the most advanced groups begin to rearrange the tissues and the levels of vascularization and cellular proliferation decrease (Souza, 2016). 
Notably, the last phase of the healing process, which is the remodeling phase, is in fact, a process that can extend for months or years after re-epithelialization. However, it is characterized by two major events: endothelial regression and remodeling of collagen fibers (Mendonça and Coutinho-Netto, 2009). Such events were evident in animals of the experimental group II, demonstrating acceleration of the healing process.

\section{CONCLUSION}

The cassava polyamide biopolymer hydrogel was efficient in supporting the healing of surgicallyinduced skin wounds in rats. It advanced the remodeling phase by some steps, characterized by the organization of connective tissue, with a parallel arrangement of collagen fibers and a reduction in fibroblasts and neoformed vessels.

\section{REFERENCES}

ARAGÃO-NETO, A.C.; SOARES, P.A.G.; LIMA-RIBEIRO, M.H. et al. Combined therapy using low level laser and chitosan-policaju hydrogel for wound healing. Int. J. Biol. Macromol., v.95, p.268-272, 2017.

BARBOZA, L.N.; PRANDO, T.B.L.; DALSENTER, P.R. et al. Prolonged diuretic activity and calcium-sparing effect of Tropaeolum majus: evidence in the prevention of osteoporosis. Evid Based. Complement. Alternat. Med., v.2014, 6p. 2014.

BERRY, I.I.; DOUGLASS, B.; SULLINS, K.E. Effects of topical application of antimicrobials and bandaging on healing and granulation tissue formation in wounds of the distal aspect of the limbs in horses. Am. J. Vet. Res., v.64, p.88-92, 2003.

BHATTARAI, N.; GUNN, J.; ZHANG, M. Chitosan-based hydrogels for controlled, localized drug delivery. Adv. Drug Deliv. Rev., v.62, p.83-99, 2010.

BRANCO-NETO, C.M.L.; RIBAS-FILHO, J.M.; MALAFAIA, O. et al. Evaluation of hydroalcoholic extract of Aroeira (Shinus terebinthifolius Raddi) in the healing process of wound skin in rats. Acta Cir. Bras., v.21, p.1722, 2006.
CHANDRA, R.; RUSTGI, R. Biodegradable polymers. Prog. Polym. Sci., v.23, p.1273-1335, 1998.

COELHO, M.C.O.C.; CARRAZONI, P.G.; MONTEIRO, V.L.C. et al. Biopolímero produzido a partir da cana-de-açúcar para cicatrização cutânea. Acta. Cir. Bras., v.17, p.1113, 2002.

FARIAS, S.S.; SIQUEIRA, S.M.C.; CRISTINO, J.H.S. et al. Biopolímeros: uma alternativa para promoção do desenvolvimento sustentável. Rev. Geon., v.7, p.61-77, 2016.

FRAIFE-FILHO, G.A.; BAHIA, J.J.S. Mandioca. Ceplac, comissão executiva do plano da lavoura cacaueira. 2009. Disponível em: <http://www.ceplac.gov.br/radar/mandioca.htm> . Acessado em: 09 dez. 2016.

ISAAC, C.; LADEIRA, P.R.S.; RÊGO, F.M.P. et al. Processo de cura das feridas: cicatrização fisiológica. Rev. Med., v.89, p.125-131, 2010.

LUCENA, M.T.; MELO-JÚNIOR, M.R.; MELO-LIRA, M.M. et al. Biocompatibility and cutaneous reactivity of cellulosic polysaccharide film in induced skin wounds in rats. J. Mater. Sci. Mater. Med., v.26, p.1-6, 2015.

MANDELBAUM, S.H. et al. Cicatrização: conceitos atuais e recursos auxiliares-Parte I Cicatrization: current concepts and auxiliary resources-Part I. An. Bras. Dermatol., v.78, p.393-410, 2003.

MARX, G.; MOU, X. Characterizing fibrin glue performance as modulated by heparin, aprotinin, and factor XIII. J. Clin. Lab. Med., v.140, p.152160, 2002.

MENDONÇA, R.J.; COUTINHO-NETTO, J. Aspectos celulares da cicatrização. An. Bras. Dermatol., v.84, p.257-262, 2009.

NAKAMURA, E.M.; CORDI, L.; ALMEIDA, G.S.G. et al. Study and development of LDPE/starch partially biodegradable compounds. J. Mater. Process. Technol., v.162-163, p.236241, 2005.

O'LEARY, R.; WOOD, E.J.; GUILLOU, P.J. et al. Pathological scarring: strategic interventions. Eur. J. Surg., v.168, p.523-534, 2002. 
OLIVEIRA, I.V.P.M.; DIAS, R.V.C. Cicatrização de feridas: fases e fatores de influência. Acta. Vet. Bras., v.6, p.267-271, 2012.

ONG, F.M.P.; RODRIGUES, L.D. Seção de experimentação. In: NEVES, S.M.P.; MANCINI-FILHO, J.; MENEZES, E.W. (Eds.). Manual de cuidados e procedimentos com animais de laboratório do biotério de produção $e$ experimentação da FCF-IQ/USP. São Paulo: FCF-IQ/USP, 2013. p.91-154.

ROSSI-JESUS, D.; BARBOSA, L.N.; PRANDO, T.B.L. et al. Ninety-day oral toxicity assessment of an alternative biopolymer for controlled release drug delivery systems obtained from cassava starch acetate. J. Evid. Based. Complem. Altern. Med., v.2015, 7p. 2015.

SAMPAIO, K.M.O.R. Tratamento da dor em pequenos animais: princípios e métodos terapêuticos. Rev. CFMV, v.16, p.43-52, 2010.

SANTOS, R.A.; FONTES, R.S. Comportamento e enriquecimento para ratos e camundongos. In: NEVES, S.M.P.; MANC INI-FILHO, J.; MENEZES, E.W. (Eds.). Manual de cuidados $e$ procedimentos com animais de laboratório do biotério de produção e experimentação da FCFIQ/USP. São Paulo: FCF-IQ/USP, 2013. p.15-41.
SMANIOTTO, P.H.D.S.; FERREIRA, M.C.; ISAAC, C. et al. Sistematização de curativos para o tratamento clínico das feridas. Rev. Bras. Cir. Plást., v.27, p.623-626, 2012.

SOTOCINAL, S.G.; SORGE, R.E.; ZALOUM, A. et al. The rat grimace scale: a partially automated method for quantifying pain in the laboratory rat via facial expressions. Mol. Pain., v.7, p.55, 2011.

SOUZA, T.A.D. Hidrogel de quitosana em diferentes graus de desacetilação na cicatrização de feridas cutâneas de ratas diabéticas. 2016. 97f. Tese (Doutorado em Ciência Animal) - Universidade Federal de Goiás - Goiânia, GO.

VAN LOO, P.L.; BLOM, H.J.; MEIJER, M.K. et al. Assessment of the use of two commercially available environmental enrichments by laboratory mice by preference testing. Lab. Anim., v.39, p.58-67, 2005. 